\title{
ILCEA
}

Revue de l'Institut des langues et cultures

d'Europe, Amérique, Afrique, Asie et Australie

23 | 2015

Le national-socialisme dans son cinéma

\section{The Münchhausen Complex: From Adaptation to Intermediality}

Der Münchhausen-Komplex: Film im Zeitalter der Medienkonvergenz

\section{Sabine Hake}

\section{OpenEdition}

\section{Journals}

Electronic version

URL: http://journals.openedition.org/ilcea/3310

DOI: $10.4000 /$ ilcea.3310

ISSN: 2101-0609

\section{Publisher}

UGA Éditions/Université Grenoble Alpes

\section{Printed version}

ISBN: 978-2-84310-305-6

ISSN: $1639-6073$

Electronic reference

Sabine Hake, «The Münchhausen Complex: From Adaptation to Intermediality », ILCEA [Online] 23 | 2015, Online since 09 July 2015, connection on 19 April 2019. URL : http://

journals.openedition.org/ilcea/3310; DOI : 10.4000/ilcea.3310

This text was automatically generated on 19 April 2019

(C) ILCEA 


\title{
The Münchhausen Complex: From Adaptation to Intermediality
}

\author{
Der Münchhausen-Komplex: Film im Zeitalter der Medienkonvergenz
}

\section{Sabine Hake}

1 What can still be said about the cinema of the Third Reich that does more than add historical details or refine critical approaches? The 1990s saw a wave of research that effectively did away with the simplistic entertainment-versus propaganda-model and introduced important revisions to the film-as-ideology model prevalent during the 1970s under the influence of the Frankfurt School. Eric Rentschler's The Ministry of Illusion (1996), Linda Schulte-Sasse's Entertaining the Third Reich (1996), Lutz Koepnick's The Dark Mirror (2002), and my own Popular Cinema of the Third Reich (2002) set out to develop a more nuanced understanding of the Nazi entertainment industry, assess generic convention and filmic styles within the continuities of German film history, reconstruct the complicated relationship between Babelsberg and Hollywood, and tease out the contradictions of popular cinema between mass deception, fantasy production, and cultural consumption. Inspired by genre studies, star studies, as well as feminist, psychoanalytical, and poststructuralist theories, more recent works on the star system (Antje Ascheid, Erica Carter), women (Jo Fox), and melodrama (Mary-Elizabeth O'Brien, Laura Heins, Astrid Pohl) have further enriched our understanding of a national (and nationalist) cinema surprisingly similar to classic Hollywood. ${ }^{1}$ Recent German-language research, which tends to be more archive-oriented, has focused on studio histories (most famously Klaus Kreimeier in The Ufa-Story), the cultural film and animated film, GermanAmerican trade relations, Nazi film activities in France, Austria, and Switzerland, as well as the careers of individual actors and directors (Kreimeier, 1996). Meanwhile, there seems to be no end to hagiographical biographies and self-serving memoirs, including recent films about filmmaking during the Third Reich, that depict the 1930s and 1940s as the golden age of German cinema and offer up its main players as embodiments of film heritage.

2 Film scholars on both sides of the Atlantic continue to publish theoretically informed accounts on the period. However, some close readings can leave us with the impression 
that all filmic meanings are indeterminate, all textual effects contradictory, and all identities on and in front of the screen contested and negotiated-making the qualifier "Nazi" more or less superfluous. Meanwhile, the vast offerings of the archive do not necessarily lead to any changes in the way we practice film history and define media culture in relation to questions of periodization and canonization. During the last decade, scholars have mostly left behind the big words (e.g. propaganda, ideology, culture industry) animating earlier research in favor of more nuanced and multifaceted perspectives; at times such efforts display the kind of antiquarian impulses that befall all subfields as they become established. As a result, the fundamental questions have almost disappeared from view: whether Nazi cinema represents merely an extreme version of, or a departure from, mainstream cinema, whether film culture in, and of, the Third Reich must be examined in European contexts or as part of a German Sonderweg in the cinema, and whether its products and practices are part of a distinctly pre-World War II history of modern mass media or a contemporary genealogy of screen cultures and their multimedial effects.

3 The last question is most relevant to the topic addressed in this essay, the critical relevance of media convergence to the Nazi culture industry, state-owned media landscape, and fascist Gesamtkunstwerk and the historical significance of Nazi cinema as a veritable laboratory of intermediality and transmediality. ${ }^{2} \mathrm{~A}$ very simply question-What does it mean to adapt a literary work to the screen?-may suffice to set up the question; yet answers cannot be found in conventional adaptation theories but only in the elusive configurations of media convergence and its contested status in film history and historiography. ${ }^{3}$

Can we think of a better film for working through some of these issues than the Ufa studio's spectacular twenty-fifth anniversary film Münchhausen(1943)? Despite its importance as a showcase of Ufa style and technology, there has been surprisingly little scholarship on one of the studio's most expensive productions and its contribution to the larger media phenomenon henceforth called Münchhausen complex. Aside from Rentschler's analysis of the film as an example of "self-reflexive self-destruction" in The Ministry of Illusion (Chapter 8), the film has attracted surprisingly little critical attention, a result perhaps of its willingness to display its intentions so openly-or at least pretend to do so. Indeed it would be easy-all too easy-to read Münchhausen's colorful mixture of history and fantasy as ideologically overdetermined. Must we not see the baron's triumphant return to Bodenwerder in the first episode as an uncanny afterimage of the enthusiastic reception of the Führer in the medieval center of Nuremberg in Triumph des Willens (1935, Triumph of the Will, Leni Riefenstahl)? And can we ignore the relevance of the various Wunderwaffen (miracle weapons) in the diegesis to the concurrent war effort? Who would not pick up on the antisemitic references behind the casting of Ferdinand Marian (of Jud Süß infamy) as the scheming Count Cagliostro (a Freemason who, in fact, was not Jewish) and the emphatic distinction by Münchhausen between the (German) will to life and the (Jewish) will to power? We might even find subversive meaning in utterances such as "The state inquisition has ten thousand arms and eyes. And it has the power to do right or wrong as it pleases" and read the preoccupation with the theme of lying as a sly commentary on the Nazi propaganda machine.

5 All these kinds of readings assume a well-established dynamics of manifest and latent contents, of surface effects and deep structures. Yet they reveal very little about the mechanisms of media self-referentiality that, as I argue, make the film part of a long 
history of translations, revisions, and adaptations. Leaving behind older concerns with textual fidelity and authenticity, we might even want to use the eponymous psychological disorder-namely, Münchausen [sic] by proxy syndrome, the fabrication or exaggeration of a child's health problems by a caregiver with the intent of drawing attention to herself -to imagine an alternative model for thinking about storytelling in a media convergence context.

But how does media convergence and related terms such as intermediality, multimediality, and transmediality allow us to move beyond traditional theories of adaptation and their shared belief in media specificity and the primacy of author and text? ${ }^{4}$ Media convergence, to offer a working definition, refers to the (diagnosis of the) gradual disappearance of the existing distinctions between film and the other arts. As defined by Henry Jenkins, media convergence engages technologies, industries, media, contents, and audiences on equal terms, and it includes the elements as well as processes of technological, economic, social, cultural, and global convergence (Jenkins, 2006). ${ }^{5}$ Most relevant for my purposes, the concept allows us to expand existing definitions of adaptation, with their appeals to an original text and attendant hierarchies of value and meaning, toward the very conditions of adaptability and translatability; of course, that does not mean that we cannot analyze the manifestations of media convergence in a specific medium such as film.

7 It is in this larger context that convergence history acknowledges film as the quintessential mixed medium of the twentieth century and examines the ways in which media convergence is articulated historically in filmic terms. Rather than tracing the adaptation of a known text from one medium (literature) to another (film), the approach favored by adaptation studies with its privileging of narrative, the study of media convergence engages the entire constellation of audiovisual practices based on the assumption that all texts are in fact intertexts. Yet in contrast to the emphasis on media specificity in what is sometimes called intermedia studies, media convergence assumes hybridization as the original condition of media culture. Beyond the false alternatives of modernist self-reflexivity and postmodern self-referentiality, film/cinema can thus be treated as an integral part both of popular culture in the traditional sense and consumer culture in its most advanced form-in this case, through industrially produced and technically based Volkstümlichkeit (folksiness, popularity). As a prime example of the latter, Münchhausen takes a populist approach to intermediality that, in contrast to modernist and postmodern understandings of self-reflexivity as critical, innovative, and subversive, aims at the audience's knowing and pleasurable participation in the making of an illusion. During the Third Reich, this kind of media-produced Volkstümlichkeit proved invaluable to redefining fantasy as a higher reality both onscreen and offscreen. I will develop this argument in a three-part fashion: Münchhausen's contribution to a long history of adaptations, the role of intermediality in the film's historical reception, and the thematization of such adaptability (in the broader sense) through the figure of the unreliable narrator.

8 The Münchhausen project was conceived as part of Ufa's twenty-fifth anniversary celebrations. The creation of a unified state-owned media company in 1942, henceforth known as the Ufi concern, provided ideal conditions for the wartime mobilization of all artistic, financial, and technical resources, including the new Agfacolor system. ${ }^{6}$ Official planning for "an Ufa anniversary film" had started in 1941 with Erich Kästner, the banned author of popular children's books, finishing the screenplay in record time by December; 
he would be listed in the credits as Berthold Bürger. (In 1951 Kästner revisited the material in a children's book called Des Freiherrn von Münchhausens wunderbare Reisen und Abenteuer zu Wasser und zu Lande.) The premiere on 3 March 1943 in Berlin's swastikadecorated Ufa-Palast am Zoo had all the characteristics of an official event, with Propaganda Minister Joseph Goebbels, less than two weeks after his infamous Sportpalast speech, and studio director Ludwig Klitzsch appearing in front of a full assembly of studio employees and with the musical program ranging from the infamous Horst Wessel song to a Festliches Präludium for organ and orchestra by Richard Strauss.

Benefitting from the iconic status of the Lügenbaron (liar baron) in the popular imagination, the filmmakers were able to ignore the typical concerns of literary adaptations (i.e. fidelity to the original text) and focus all attention on the spectacular aspects of the production itself. Directed by Josef von Baky, the film brought together several major Ufa stars, including Hans Albers in the title role, Käthe von Nagy, Brigitte Horney, and Ilse Werner, with the women drawing on their respective screen personas as the good wife, the femme fatale, and the ingénue. Theo Mackeben student Georg Haentzschel composed a lush score whose leitmotif structure conveys a distinctly elegiac, melancholy mood. Costume designer Manon Hahn expertly applied the lessons learned from the Olympus setting in Amphitryon (1935, Reinhold Schünzel) to her first film assignment in color. And taking advantage of the studio's vast archive of stage props and historical costumes, set designers Emil Hasler (together with Otto Gülstorff) created "600 buildings, 2,500 sketches and drawings, and 30 models" and used elaborate trick sequences by acclaimed cinematographer Konstantin Irmen-Tsched to visualize the hero's “wonderful travels and adventures through the centuries" (Rother, 1993).

The Münchhausen tales have been a source of inspiration for writers and artists since the eighteenth century. This is not the place to speculate about the reasons for the figure's enduring popularity except to point to the inherent productivity of lying as a narrative device and to acknowledge the close affinities between adaptation and revision as compatible aesthetic strategies. In the process, the historical figure of Hieronymus Carl Friedrich von Münchhausen (1720-1797) was transformed into a fictional character also known as Baron Münchausen, with the disappearing " $h$ " a telling sign of his universal adaptability. Through countless tales known as Münchhausiaden, the various contributors turned the infamous baron into "an eternal figure for all times", to quote the Ufa Magazin from March 1943. Two key texts established the model for such an expanded understanding of adaptation / translation as a form of lying, the retranslation by Rudolf Erich Raspe (from the English) of the stories of Baron Hieronymus Karl Friedrich von Münchhausen by Gottfried August Bürger as Wunderbare Reisen zu Wasser und zu Lande: Feldzüge und lustige Abenteuer des Freiherrn von Münchhausen (1786) and its further Germanization by Karl Immermann in Münchhausen: Eine Geschichte in Arabesken (1838). With the problem of origins forever obscured, the frameworks of reference could henceforth be adjusted to changing interpretations. Significantly, the Deutsche Buchgemeinschaft republished the Immermann version in 1933 with an afterword by Jacob Wassermann that locates the title figure within an invented tradition of the Volkssage indifferent to any claims to authenticity; after all, in the apocryphal words of Münchhausen as channeled by Immermann, "I came, saw-and lied". Turning lying into a veritable science, the 1940 two-volume edition of the Immermann novel even included a pseudoscientific index of names prepared by Oskar Weitzmann. Meanwhile Reclam in 1943 reissued the Bürger version edited by Karl Walt Schmidt as "the book to the film", 
together with several editions marketed specifically to younger readers, thereby confirming the multidirectional nature (i.e. from film back to literature) of the adaptation process.

11 While the combination of text and image gave rise to the Münchhausen complex during the eighteenth and nineteenth centuries, the twentieth century, the century of media convergence, provided almost unlimited new opportunities for exploring the figure's filmic, dramatic, and musical potential. A few animated shorts and short features were made during the 1920s, emphasizing the fantastic elements in the tradition of Georges Méliès's 1905 Le voyage de la lune (A Trip to the Moon); Die Abenteuer des Herrn Baron Münchhausen, oder Die Wahrheit über alles (1931, The Adventures of Mr. B. M., Peter Peroff) continued in that tradition. Meanwhile a 1928 operetta by Felix Döhrmann, Bela Jenbach, and Ernst Stefan, a 1933 opera by Mark Lothar, and a 1934 comedy by Rudolf Presber explored the liberating effects of lying as a strategy for dealing with difficult social realities. Confirming the perfect fit between the Lügenbaron and Nazi event culture, the year 1936 saw the opening of a Münchhausen museum in Bodenwerder, the family's ancestral home and a small town in Lower Saxony that allowed visitors to partake in his exotic adventures from within the comforts of German provincialism. The war years brought further revisions with a clear nationalist agenda. Confirming the broad, inclusive appeal of the liar's perspective, even Münchhausen: Ein deutsches Schauspiel (1900) by banned writer Herbert Eulenberg was reprinted in 1940. Meanwhile Karl Theodor Haanen reinvisioned the baron as a contemporary soldier in Der Flieger-Münchhausen (1938, Flier M.) and Flaksoldat Münchhausen (1943, Soldier M.); both books were included in the list of censored woks after 1945.

If we want to argue in favor of intermediality and media convergence as the most productive ways of thinking about a film like Münchhausen, we obviously need to move beyond the thematic focus on the title figure and include the resonance of other texts and media within the film. This means paying close attention to the tension between narrative and spectacle that is characteristic of the period film as a whole but that assumes special relevance through the film's unique combination of history, adventure, and fantasy. Time and again, the theatrical mise-en-scène in Münchhausen arrests the flow of the narrative in order to showcase set and costume design. The spectacular interiors and animated crowd scenes frequently overwhelm the frame, an effect that simulates the exaggeration in the narrative on the visual level. Rather than facilitating psychological motivation or increasing narrative suspense, this overwhelming presence of the other arts in fact becomes the primary instrument in the making of filmic self-referentiality and its spectatorial effects.

13 In achieving these effects, the filmmakers drew heavily on the genre of the Ausstattungsfilm (period film) that had long served as a laboratory for the studio's artisanal mode of production and contributed to the privileging of mise-en-scène over narrative continuity in the famed Ufa style. Yet the Babelsberg blockbuster also found plenty of inspiration in the Hollywood dream factory, with its fairytale elements clearly influenced by The Wizard of $\mathrm{Oz}$ (Victor Fleming, 1939) and its orientalist kitsch reminiscent of the British The Thief of Bagdad (Michael Powell, 1940). The generic conventions associated with fantasy in the broader sense established the conditions under which episodic storytelling, unreliable narration, and special effects could become synonymous with the making of a higher filmic reality. Throughout familiar iconographies established a framework of referentiality for contemporary audiences: of a simultaneously imperial 
and folkloristic Czarist Russia for the St Petersburg episode (e.g. Marlene Dietrich in Josef von Sternberg's 1934 Scarlet Empress), of nineteenth-century orientalism for the Constantinople episode (e.g. Mozart's The Abduction from the Seraglio), and of eighteenthcentury painting for the Venice episode (e.g. Canaletto's vedute). The harem sequence, more specifically, cites the aesthetics of the tableaux vivants, with Wilhelm Prager's cultural film Wege zu Kraft und Schönheit (Ways to Strength and Beauty, 1925) a recognizable inspiration. Visually most compelling, the moon sequence cites the art nouveau style with its organic shapes and ornamental flourishes, creating an atmosphere of morbid decadence difficult to reconcile with Nazi dreams of military conquest and final victory.

Going even further into the genealogies that establish Münchhausen as a multimedia phenomenon, we must also pay special tribute to the artists who have illustrated his tales throughout the centuries and established a visual catalogue for his most famous adventures, beginning with the ride on the cannonball. A lost 1752 portrait by G. Bruckner of Münchhausen in the uniform of the Brunswick Cuirassiers Regiment remains the only existing historical document, preserved through numerous copies of said painting, but the sartorial markers of his persona-e.g. the tricorne and dolmanwere already early on codified through book illustrations by August von Wille for an 1856 edition of the Bürger book in the series Deutsche Volksbücher and by Gustav Doré for a 1862 French translation by Théophile Gautier fils. Colorful postcards with episodes illustrated by Oskar Herrfurth appeared in the late nineteenth century and contributed to the dissemination of the Münchhausen tales into an emerging commodity culture that included lead figures and board games and today continues with posters mugs, totes, and $\mathrm{t}$-shirts. In the process, Münchhausen became the most translated and most illustrated book of tales, with recent accounts listing more than three hundred illustrators, from well-known artists such as Alfred Kubin and Josef von Diveky (of the Wiener Werkstätte) to minor folk and genre painters such as Phillip Sporrer, Alfred Hoffmann-Stollberg, and Paul Leuteritz.7 Primarily geared toward children, most illustrated books feature adventures involving wild animals and natural hardships, whereas the 1943 film clearly prefers the confrontation with beautiful women and political enemies, and does so for reasons to be considered later.

To move to my second point, the importance of intermediality to the Nazi culture industry can be reconstructed through the film's contemporary reception and the critics' almost fetishistic fascination with the technology of film-a mode of reception that contradicts simplistic views of Nazi cinema as mass deception. As reviewers noted at the time, the filmmakers utilized the entire range of techniques and technologies, including the new Agfacolor system with its intense reds and greens and subtly nuanced pastels. Old-fashioned wires and pulleys may have been used to stage Münchhausen's fight against animated pieces of clothing presumably afflicted by rabies. But the more interesting effects were achieved through the discourse of self-reflexivity that blurred the boundaries between fantasy and reality and made possible a sustained reflection on the technologies of image production.

The overwhelmingly positive reviews acknowledged these filmic means of production in enthusiastic descriptions of "a bright, intense flood of colors" and its powerful effect on the audience: "The technical surprises! How often was there spontaneous applause." Fantasy, all agreed, had finally overcome the constraints of the real and established a new framework for creating truth effects: "This film is a triumph of the imagination, a delicious leap over all boundaries of reality into the miraculous gardens of dream and 
play [...] [proof] that a person with a richer imagination can also force a richer world into being." Fantasy and reality, folklore and technology-in Nazi discourse, these terms no longer represented opposites but were in fact thought of as mutually constitutive. Most reviewers paid no attention to the fact that the Münchhausen film was a literary adaptation. In fact, the suggestions for good ad copy in the trade press made the literary tradition merely one component in the intended convergence of Volkstümlichkeit and modern technology. "Humor, folksiness, and the adventurous nature of romantic German literature, transfigured and deepened through the poetic fantasy of film", read one suggestion. Another recommendation to theater owners asserted that, "with the greatest of all Ufa films, the most popular of the arts bears witness to the miracle of fantasy, elevating Münchhausen, the immortal popular hero, to the personification of eternal German yearning!" 10

The obvious goal behind such advertising slogans was to make filmmakers and audiences complicit in the creation of a filmic fantasy. The underlying implications are spelled out in a revealing comment by reviewer Ilse Urbach on desirable audience responses:

Just as the two adventurers [Münchhausen and his manservant, $\mathrm{SH}$ ] trained their visual senses in the course of their travels, the audience of the Münchhausen stories needs to develop a heightened mode of perception: they must remove themselves from everything real and become able to look into the realm of possibility [...] ready to forget reality. ${ }^{11}$

Confirming her point, references to the act of looking can be found in the film's many images of windows, screens, and veils, the various sighting devices and, not to forget, the filmic reflection on light and darkness (e.g. in the duel scene) that identifies the basic elements of spectatorship in the diegesis. Declaring such self-referentiality as the essence of film as a popular/populist medium, Hans Jenkner in Der Angriff unintentionally acknowledged the ideological function of such media self-reflexivity when he concluded, "that the immortal Lügenbaron has become the representative of the purest filmic truth". ${ }^{12}$ Praising the film's contribution to modern folklore, the reviewer in the Völkischer Beobachter saw a long-awaited return to the magic of the laterna magica; only in this case, the "lantern" uses electricity to create "a fairytale for adults who in the twentieth century only need to reach toward the light switch to scare away the colorful dream". ${ }^{13}$ Significantly, it was the audience's awareness of the interplay of illusion and truth that, in the opinion of yet another reviewer, made film the most powerful repository of the imagination in the contemporary world: "This Ufa anniversary film punches a hole in the facade of reality and clears a path in favor of fantasy [...] Even pessimists who feared that the film strip would strangulate the imagination should bury all of their concerns after seeing this film." ${ }^{14}$

The filmic thematization of time and space in Münchhausen illustrates well the benefits of an expansion of the adaptation model toward the effects of intermediality. Beyond the original promise of eternal youth made by Cagliostro in the diegesis, the film offers multiple perspectives on the spatio-temporal dynamic: through the different means of transportation (e.g. a horse, cannonball, barque, and hot air balloon) that allow for quick escapes over vast distances; through the reflections on the passing of time (e.g. in Münchhausen's comment on his 163 days and nights in St Petersburg and in the sultan's grotesque scenario of a human stopwatch); and, finally, through the time-lapse photography that empowers the fast runner in the Turkish episode and facilitates the rapid change of seasons on the moon. Time-lapse animates the battle scenes, whereas rear projection (i.e. the well-known Schüfftan effect) makes possible the reenactment of 
Münchhausen's famous ride on the cannonball. Several times, the introduction of models into the frame allows for elaborate travelling shots that radically redefine filmic space. Multiple exposures are enlisted to simulate invisibility or hypervisibility (e.g. the abduction of Isabella d'Este, Münchhausen's duel with her brother) and to suggest omnipotence in the field of vision. Repeatedly special effects serve to explore film's relationship to the other arts, for instance when Cagliostro makes the nude woman in a painting turn toward the observer, or when he conjures up string instruments on the soundtrack to accompany his piano performance. Even the film music proceeds not only through an elaborate leitmotif structure but also includes moments of Mickey Mousing in which sound effects are synchronized with movements (e.g. in the runner scenes).

My discussion of the film's place in a longer history of media convergence and my overview of its contemporary reception have shown that the tales of the Lügenbaron, the quintessential unreliable narrator, provided Nazi audiences with a unique perspective from which to blur the boundaries between fantasy and reality, fiction and truth. But the film also established a model for doing away with the distinctions evoked under the heading of "film and the other arts". Both strategies served to demonstrate the power of film to appropriate, incorporate, and reconfigure existing art forms and artistic traditions. As the essay's third part on the role of narrative strategies in the reenactment of media convergence suggests, Münchhausen thematizes this process by telling several stories about lying in a lying voice, with the constitutive terms defined through the framing story and its narrative point of view.

The film begins in what looks like the eighteenth century-and what turns out to be a costume ball at the Münchhausen estate in Bodenwerder. In the same way that the illusion of history is revealed through technology, in this case a light switch and an automobile, the larger reflections on lying, the famous Lügengeschichten, are initiated by an overenthusiastic Münchhausen scholar who persuades the baron to recount some of the fantastic adventures of his presumed ancestor and who, in the ending's final moment of truth, outs himself as said ancestor. The four episodes in flashback mode transport Münchhausen and his manservant to the court of Catherine the Great in St Petersburg, Constantinople during the Ottoman Empire, Venice in the midst of carnival, and, after a balloon ride, the rather inhospitable wrong side of the moon. Designed to showcase the two sides of the Albers persona, the cocky adventurer and the brash seducer, these four episodes establish a close connection between sexual conquest and military warfare. They have little in common with the Raspe, Bürger, and Immermann tales where the baron encounters stags, hounds, bees, ducks, bears, as well as a range of historical personalities. Adapting these earlier versions to the screen in 1943 clearly meant emphasizing a very different motive behind Münchhausen's quest for adventures, his flight from maturity. The sexual pursuit of women and the fear of sexual women must be considered as the two corresponding manifestations of his refusal to fulfill the social contract of adulthoodthat is, of marrying and starting a family. Under these conditions, the gift of immortality, given to the baron by Count Cagliostro, legitimates the principle of repetition and the refusal of closure that links Münchhausen's psychosexual pathology to the film's episodic structure. Of course, the same principle of generativity, namely in the form of cultural tradition, is at work in the process of adaptation. But even with an episodic structure, all stories-unlike adaptations-will eventually end. In accordance with the doubling of narrative structure and psychosexual biography, the ending must acknowledge the desire for love and the acceptance of death as essential aspects of the human condition. 
21 It is this important insight that also holds together the framing story and reveals the fear of death as the driving force behind all storytelling. The transition from the reference during the costume ball to stories being told to the actual conditions of storytelling in the garden begins with a closeup of the baron dressed in a 1940s double-breasted suit, followed via superimposition by a closeup of an illustrated book containing his most famous tales. Ignoring admonitions by wife in the offscreen, he first asserts that, "I will tell these stories" but then lists the stories (i.e. those in the book) that will not be told. His reflections on Münchhausen as "a Copernican man" are presented through elaborate camera movements that end with another closeup on his face, with the soundtrack facilitating the transition to the real eighteenth century as the test case for the baron's larger than life existence. Ensuring the attention of its audiences, the film returns briefly to a group of listeners around the coffee table after the Russian episode and confirms imagination as a higher form of reality. To the question of the young woman: "Did Münchhausen really live longer than other people?" Münchhausen responds with the standard ending of German fairytales: "Und wenn er nicht gestorben ist, lebt er noch heute", usually translated as "they lived happily ever after".

The return to the framing story is announced through the symbolic significance of smoke (and mirrors). After his manservant dies on the moon, turning into ashes, Münchhausen decides to renounce the gift of time and join his wife in the present-which also means in mortality. As he continues to recall his adventures throughout the nineteenth century, his young listeners become increasingly unsettled by the possibility that their host might in fact be his famous ancestor. Significantly, Münchhausen's confession is structured around world historical events to which the eager scholar provides the dates-1789, 1814, 1848 , and 1867-that also recount the making of the German nation state. It is against this background that the intercutting between Albers and his portrait on the wall and the writing of "The End" in the smoke of an extinguished candle shows one last time the power of cinema to carry the process of adaptations into the future, and do so precisely through the mobilizing of all media technologies-namely, of image, voice, music, and text.

Beyond the framing story, Münchhausen reflects on the uniquely filmic conditions of storytelling through the figure of the unreliable narrator and the various stories told inside the narrative, whether in the form of recollections, confessions, or wagers (e.g. the Tokai bet). The close attention to the relationship between showing and telling-and, not to forget, listening-is achieved through a well-known paradox, namely Münchhausen's status as a confirmed liar and unreliable narrator, with both positions serving slightly different epistemologies. Whereas the problem of credibility associated with the unreliable narrator is ultimately irresolvable-he may, after all, be telling the truth-, the narrator as liar actually achieves the opposite effect. For by making deception an integral part of his tall tales, he effectively does away with the need for truth; henceforth, the sole criterion for evaluating a narrative element or entire tale becomes their ability to inspire shock and awe in the audience. The storyteller's claims on the superiority of deception, in turn, are based on three facts: the audience's familiarity with the figure as a liar, the failure of his tales to satisfy even minimal standards of probability, and the character's own references to the elusiveness of truth and his insistence on the necessity of illusion. Under these conditions, filmic representation can no longer be measured against any standards of realism and its presumed opposite, illusionism, but must be appreciated for the generative potential shared by both representational modalities. Significantly, this 
position is identified with the discourse of the omniscient narrator, also known as the cinema of narrative continuity, that controls any destabilizing effects introduced by the unreliable narrator and, in so doing, shifts attention to the nature of film as the quintessential mixed medium.

Through the unreliable narrator figure in the diegesis and the omniscient narrator position of classical cinema, Münchhausen facilitates forms of engagement unique to the split consciousness of film since its earliest beginnings-namely, the split between narrative and spectacle and its resonances in the self-definition of film as art, technology, and commodity. Already in the framing story, the narrator is introduced as a figure of spectatorial desire: by his indulgent wife but, more importantly, by the overeager Münchhausen scholar and his flirtatious fiancée. The primacy of spectatorship and visual spectacle is confirmed by the camera's focus on Albers's steely blue eyes in chiaroscuro lighting, with his gaze always directed somewhere beyond the frame. The transformation of the storyteller and main character into a visual spectacle takes place through the means of costume design, with the physical body (and its erotic potential) strangely missing from view. From the colorful dress uniforms to the elegant morning coats, Münchhausen's costumes are a demonstration of sartorial splendor. Made of silk, lace, brocade, velvet, fur, and adorned with feathers and jewelry, they conjure up an atmosphere of luxury and sensuality. But in the form of ethnic costumes (e.g. the Turkish costume of fez, vest, cummerbund, and balloon pants), they also establish a clear connection between performance and masquerade as forms of adaptation and, to return to the Münchhausen theme, of lying. This connection is openly explored in numerous scenes of dressing and undressing rarely associated with masculinity but justified here through the narrative conceit of external dangers and constraints.

One of the effects of the reflection on storytelling and the emphasis on visual spectacle is a general weakening of character identification. As an unreliable narrator, Münchhausen does not need our empathy or sympathy; those feelings are reserved for decidedly mortal figures such as his wife, his manservant, and (interestingly) Cagliostro, who together with Casanova functions as the title figure's secret double. ${ }^{15}$ Whereas the elderly Casanova makes only a brief appearance, a good indication of the limited relevance of sexual desire to narrative motivation, Cagliostro appears twice, the second time in a sequence that offers the film's most significant commentary on the art of filmmaking. The Münchhausen-Cagliostro relationship must be described as one of mutual recognition in both their similarity and complementarity. In a dark room that recalls an alchemist's laboratory, Cagliostro gives Münchhausen two gifts, the power of controlling visibility and of stopping the aging process. In so doing, the count effectively serves as a stand-in for the filmmaker in the diegesis. His ability to make the nude woman in the painting turn toward the two men recalls the work of the cinematographer/director, and his ability to conjure an imaginary chamber orchestra resembles the work of the film composer/sound technician. Like Cagliostro, the cinema, too, fulfills a rarely addressed wish by its contemporary audience (not counting Joseph Goebbels's famous Kolberg speech about war and cinema), namely to create a time capsule of its desires for future generations.

As the project of media convergence continues in the digital age, the 1943 Münchhausen film has survived in numerous digital versions that repeat the motif of lying in film historical versions of Vergangenheitsbewältigung and its respective falsifications. In the Federal Republic, a 1953 rerelease of the Nazi production (at 90 instead of the original 
134 minutes) listed Kästner as the screenwriter but deleted the framing story; on film posters, the "Ufa Farbfilm" of 1943 was now called "the greatest German color film". In the German Democratic Republic, the scenes with Catherine the Great were simply deleted and, in reruns on state television, references to the film's fascist past avoided. Recent DVD rereleases continue to present the 1943 production with various lengths between 90-110 minutes and, in the obligatory DVD extras, advertise it as a big production from "the golden age of German film". After the war, two contemporary appearances of the Münchhausen figure, sharing little more than the name with their namesake, sought to benefit from the figure's easy adaptability. Thus in the West, a musical comedy/adventure with teen idol Peter Alexander became Münchhausen in Afrika (1958, M. in Africa, Werner Jacobs); in the East, cabaret artist Wolfgang Neuss made a Cold War satire about Genosse Münchhausen (1962, Comrade M.). More recent international productions and German television features tend to limit themselves to the fantastic and comic elements, as evidenced by Terry Gilliam's blockbuster The Adventures of Baron Munchausen (1988) with John Neville and the two-part ARD television production with Jan Josef Liefers, Baron Münchhausen (2012, Andreas Linke). A recent docudrama, Münchhausen: Die Geschichte einer Lüge (2013, M.: The Story of a Lie, Kai Christiansen) with Ben Becker, seeks to reclaim the historical figure from the so-called web of lies-in short, the images and stories that have formed around him since the mid-eighteenth century.

While exceptional in many ways, the Münchhausen film shows that a significant part of the power of cinema remains unaccounted for in textual readings that treat films as selfcontained works of art and in contextual readings that privilege social and political interpretations. The case study presented in this essay suggests that all feature films are adaptations of some form or another, and that the recognition of a film's intertextual effects goes a long way in making sense of its popular appeal and discursive power. For these reasons, a shift in methodology from the study of individual filmic texts to case studies in media convergence is bound to fundamentally expand our understanding of film as the quintessential mixed medium defined by its remarkable ability (learned, of course, from other art forms and media technologies) to remix and reboot existing stories, iconographies, traditions, conventions, and styles. It is also precisely this extreme adaptability that enables feature films to serve two seemingly contradictory functions, to create a compelling fantasy and reveal its conditions of production, to become subject to the seductions of an unreliable narrator and to maintain the position of absolute authority claimed by classical narrative.

What are the broader implications for our understanding of intermediality and, to return to the questions raised in the beginning, the study of Nazi cinema? As I have argued, the Münchhausen complex scrambles the discourses of art, technology, politics, and entertainment that inform prevailing methodologies in the study of this difficult historical period. But these old and new genealogies can only be reconstructed through the detour of film history as the history of media convergence, including its institutional and technological aspects. Without greater attention to current debates on intermediality, multimediality, and transmediality in film and media studies and the potential contribution of film historical research to these debates, we may become trapped in an increasingly marginal subfield of German film studies that produces ever more nuanced readings-but with less and less awareness of their relevance to the present conjuncture. 


\section{BIBLIOGRAPHY}

AscheID Antje (2003), Hitler's Heroines: Stardom and Womanhood in Nazi Cinema, Philadelphia: Temple University Press.

CARTER Erica (2004), Dietrich's Ghosts: The Sublime and the Beautiful in Third Reich Film, London: BFI.

DöRmann Felix, Jenbach Bela \& Stefan Ernst (1928), Münchhausen, Vienna: Ludwig Doblinger.

Fox Jo (2000), Filming Women in the Third Reich, Oxford: Berg.

HAANEN Karl Theodor (1938), Der Flieger Münchhausen: Freiherr von Münchhausen erzählt unglaubliche Fliegerabenteuer, Stuttgart: Derold.

HAANEN Karl Theodor (1943), Flaksoldat Münchhausen: Neue Lügengeschichten, Essen: Wilhelm Spael. HAKE Sabine (2002), Popular Cinema of the Third Reich, Austin: University of Texas Press.

HEINs Laura (2013), Nazi Film Melodrama, Urbana: University of Illinois Press.

JenKIns Henry (2006), Convergence Culture: Where Old and New Media Collide, New York: New York University Press.

KoEPNICK Lutz (2002), The Dark Mirror: German Cinema Between Hitler and Hollywood, University of California Press: Berkeley.

KREIMEIER Klaus (1996), The Ufa Story: A History of Germany's Greatest Film Company, 1918-1945, trans. Robert and Rita Kimber, New York: Hill and Wang.

LEITCH Thomas M. (2003), “Twelve Fallacies in Contemporary Adaptation Study”, Criticism, 45(2), $149-71$.

LoTHAR Mark (1933), Münchhausen, Berlin: Adolph Fürstner.

O'BRIEN Mary-Elizabeth (2004), Nazi Cinema as Enchantment: The Politics of Entertainment in the Third Reich, Rochester: Camden House.

РетHö Agnes (2005), “Intermediality in Film: A Historiography of Methodologies”, Varda Acta Universitatis Sapientia, Film and Media Studies, 2, 39-72.

PoHL Astrid (2010), TränenReiche BürgerTräume, Munich: edition text + kritik.

PRESBER Rudolf (1934), Münchhausen: Komödie in vier Akten, Berlin: Vertriebsstelle und Verlag Deutscher Bühnenschriftsteller und Bühnenkomponisten.

RAJEWKSY Irina (2005), “Intermediality, Intertextuality, and Remediation: A Literary Perspective on Intermediality", Intermédialités, 6.

RENTSCHLER Eric (1996), The Ministry of Illusion: Nazi Cinema and Its Afterlife, Cambridge, MA: Harvard University Press.

RoTHER Rainer (dir.) (1993), Die Ufa 1917-1945: Das deutsche Bilderimperium, Nr. 19, Münchhausen, Berlin: Deutsches Historisches Museum, n.p.

SCHUlte-SASSE Linda (1996), Entertaining the Third Reich: Illusions of Wholeness in Nazi Cinema, Durham, NC: Duke University Press. 
SCHWEIZER Werner R. (1969), Münchhausen und Münchhausiaden: Werden und Schicksale einer deutschenglischen Burleske, Berne: Francke.

STAM Robert \& RAENGO Alessandra (dir.) (2005), Literature and Film: A Guide to the Theory and Practice of Film Adaptation, Oxford: Blackwell.

WACKERMANN Erwin (1969), Münchhausiana: Bibliographie der Münchhausen-Ausgaben und Münchhausiaden, Stuttgart: Fritz Eggert.

\section{NOTES}

1. For the main book publications in English, see Rentschler (1996), Schulte-Sasse (1996), Fox (2000), Hake (2002), Koepnick (2002), Ascheid (2003), O’Brien (2004), Carter (2004), Pohl (2010), and Heins (2013).

2. In describing a heterogeneous field of inquiry, Irina Rajewsky (2005: 47-9) distinguishes between "intermediality as a fundamental condition or category" that functions as an integral part of cultural production, "intermediality as a critical category for the concrete analysis of individual media products and configurations", and the kind of intermediality that "operates at the level of the analyzed phenomena per se" and includes media transposition (e.g. film adaptation of a novel), media combination (sound film as the combination of image and sound), and intermedial references (e.g. filmic writing in literature). For an overview of recent debates in the field, also see Pethö (2005).

3. As Thomas Leitch (2003: 149-71) has shown, the relationship between literature and film, which has been at the center of adaptation studies, remains woefully undertheorized. If adaptation, to summarize some of his points, means the movement from one medium to another, what do we make of the fact that film is both multimedial and a medium in its own right? How are we to define the relationships among related literary texts and earlier filmic adaptations? And in what ways does the implicit belief in media specificity limit our understanding of film/ cinema as a visual, narrative, musical, acoustic, dramatic, social, and spatial medium? Under the conditions of intertextuality, how is the originality of, or fidelity to, a source text to be defined? Leitch's recasting of the problematic through a set of new questions-"How and why does one particular precursor text come to be privileged above all others in the analysis of a given intertext? What gives some intertexts but not others the aura of texts?"(168)-sheds an important light on the continuing appeal of the 1943 Münchhausen film; but it does not address the multimedia character of that film in its own historical context. For a survey of contemporary debates in adaptation studies, also see Stam \& Raengo (2005).

4. Throughout these terms will be used in recognition of their slightly different meanings in the scholarship, with intermediality exploring the relationship between media, multimediality emphasizing the interplay among several media, and transmediality focusing on phenomena not specific to one particular medium.

5. The definition is taken from <http://web.mit.edu/cms/People/henry3/converge.pdf>.

6. A documentary on the history of the color film, Ein Mythos in Agfacolor (2005, Gerd und Nina Koshofer) can be found among the DVD extras of the Transit Classics Deluxe-Edition.

7. The first account was by Wackermann (1969); recent numbers are cited in < www.munchausen.org/en/library_en.htm>. An early overview of the many adaptations can be found in Schweizer (1969).

8. Hans-Ottmar Fiedler, "Ein Triumph der Farbe”, Berliner Lokal-Anzeiger, 5 March 1943. Original: “ eine bunte, stürmische Flut der Farben"; "Die technischen Überraschungen! Wie oft gab es nicht Beifall mitten ins Bild hinein." 
9. Paul Beyer, review of Münchhausen, Leipziger Neueste Nachrichten, 24 July 1943. Original: “Dieser Film ist ein unumschränkter Triumph der Phantasie, ein köstlicher Sprung über alle Zäune der Wirklichkeit hinüber in die Wundergärten des Traums und schwerenlosen Spiels [...] daß ein Mensch mit reicherer Einbildungskraft sich auch eine reichere Welt erzwingen kann."

10. Suggestions for add copy in Der Film-Kurier, 3 March 1943: "Heiterkeit, Volkstümlichkeit und Abenteuerseligkeit romantischer deutscher Dichtung, verklärt und vertieft durch die dichterische Phantasie des Films!"; "Mit dem größten aller bisherigen Ufa-Filme bekennt sich die volkstümlichste der Künste wieder zum Wunder der Phantasie, Münchhausen, den unsterblichen Volkshelden, zum Sinnbild einer ewigen deutschen Sehnsucht erhebend!" This recommendations anticipates a later discussion on the relationship between film and fantasy that involved the director of Münchhausen; see Fritz Theodor Fabius, "Phantasie und Wirklichkeit. Anmerkungen anlässlich einer Unterhaltung mit dem Spielleiter Josef von Baky", Film-Kurier, 3 March 1944.

11. Ilse Urbach, review of Münchhausen, Das Reich: Deutsche Wochenzeitung, 14 March 1943. Original: "Während die beiden Abenteurer ihre Sehorgane wunderbar geschärft haben für die Weite dieser Welt, bedarf es bei dem Betrachter der Münchhausiaden eines noch gesteigerten Gesichts: er mu $\beta$ sich von allem Wirklichen entfernen, hineinschauen können in das Reich der Phantasie [...] Unter dem Flitterwerk des bunten Bilderbuches vergißt man gern die Wirklichkeit [...]."

12. Hans Jenkner, review of Münchhausen, Der Angriff, 10 March 1943, n.p. Original: "[...] daß der unsterbliche Lügenbaron zum Träger reinster filmischer Wahrheit geworden ist."

13. Richard Biedrzynski, review of Münchhausen, Völkischer Beobachter, 6 March 1943. Original: “[... ] ein Märchen für Erwachsene, die im zwanzigsten Jahrhundert nur nach dem Lichtschalter zu greifen brauchen, um den bunten Traum zu verscheuchen."

14. Werner Fiedler, Deutsche Allgemeine Zeitung, 5 March 1943. Original: "Dieser Jubiläumsfilm der Ufa schlägt beherzt ein Loch in die Fassade der Wirklichkeit, eine Bresche für die Phantasie [...] Selbst Pessimisten, die fürchteten, das Filmband könne allmählich zur Schlinge werden, in der die Phantasie erdrosselt wird, dürften nach diesem Farbfilm die letzten Besorgnisse begraben."

15. With some trepidation, L. Krabbe discussed the triangular relationship during the production of the film in "Münchhausen-Casanova-Cagliostro", Film-Kurier, 29 March 1942.

\section{ABSTRACTS}

Nazi cinema took full advantage of the possibilities of media convergence by relying heavily on literary adaptations and the close relationships between film and the other arts. These textual strategies and their ideological effects are on full view in Münchhausen (1943), one of the most expensive and successful films of the Third Reich. The film about the famous Lügenbaron allows us to consider the pivotal role of media convergence in the making of the first modern media dictatorship and develop more complex models beyond close textual reading and historical contextualization that account for the dynamic interplay of film art, politics, and technology.

Das Kino im Nationalsozialismus nutzte die Möglichkeiten der Medienkonvergenz durch die vielen Literaturverfilmungen und die engen Beziehungen zwischen Film und anderen Künsten voll aus. Diese textuellen Strategien und deren ideologische Effekte sind besonders deutlich in Münchhausen (1943), einem der teuersten und erfolgreichsten Filme des „Dritten Reiches“. Der Film über den berühmten Lügenbaron ermöglicht es uns, die zentrale Rolle der Medienkonvergenz in der Entstehung der ersten modernen Mediendiktatur aufzuzeigen und 
neue Ansätze jenseits von Textanalyse und historischer Kontextualisierung zu entwickeln, die der komplexen Dynamik von Filmkunst, -politik, und -technologie Rechnung tragen.

INDEX

Schlüsselwörter: Film im Nationalsozialismus, Münchhausen, Adaption, Intermedialität, Medienkonvergenz

Keywords: Nazi Cinema, Münchhausen, adaptation, intermediality, media convergence

\section{AUTHOR}

\section{SABINE HAKE}

Sabine Hake is Professor and Texas Chair of German Literature and Culture in the Department of Germanic Studies at The University of Texas at Austin. A cultural historian working on twentieth century German culture, she is the author of six monographs, including German National Cinema (2008, second revised edition), Topographies of Class: Modern Architecture and Mass Society in Weimar Berlin (2008), and Screen Nazis: Cinema, History, and Democracy (2012). This article is part of a current research project on German cinema in the age of media convergence. 